(c) American Dairy Science Association, 2006.

\title{
Effect of Different Forms of Methionine on Lactational Performance of Dairy Cows
}

\author{
H. Rulquin, ${ }^{*}$ B. Graulet, $\dagger^{1}$ L. Delaby, ${ }^{*}$ and J. C. Robert $\dagger$ \\ *Unité Mixte de Recherches Production du Lait, Institut National de la Recherche Agronomique, 35590, Saint-Gilles, France \\ †Center of Evaluation and Research in Nutrition, Adisseo France SAS, 03600, Commentry, France
}

\begin{abstract}
Methionine is one of the first limiting AA in dairy cows. The use of rumen-protected Met to correct deficient diets is limited by the lack of a product that could be incorporated into a pelleted concentrate. The main objective of this trial was to test, at practical doses (approximately $10 \mathrm{~g}$ of absorbable Met), the efficacy of 2 forms of pelletable Met hydroxy analogs, D,L-2hydroxy-4-(methylthio)-butanoic acid (HMB) and the isopropyl ester of HMB (HMBi), to provide Met to cows, especially for milk protein synthesis, compared with a negative control and to Smartamine M (SmM). These treatments were tested according to a $4 \times 4$ Latin square in 16 Holstein cows. Plasma Met concentrations were increased by 110 and $65 \%$ that of the control value after HMBi and SmM treatments, respectively. Milk protein yield increased by 32 and $41 \mathrm{~g} / \mathrm{d}$ for HMBi and SmM, respectively. D,L-2-Hydroxy-4-(methylthio)-butanoic acid supplementation did not improve Met availability to the cows for milk protein synthesis. The HMBi treatment induced an increase in 15:0 in milk at the expense of a general reduction in even-numbered shortand medium-chain fatty acids. Moreover, HMBi and SmM supplements led to an increase in the saturation level of $\mathrm{C}_{18}$ fatty acids consistent with the improvement of Met supply. It was concluded that HMBi is a new "rumen-protected" form of Met that can be supplied to cows integrated into pellets.
\end{abstract}

Key words: rumen-protected methionine, bioavailability, milk protein, dairy cow

\section{INTRODUCTION}

Increasing the milk protein content is an important objective for dairy producers, but it necessitates a supply of postruminal AA adequate for the respective requirements of the cow. The extent and sequence of limitation of some AA appear to be affected primarily by

Received November 22, 2005.

Accepted May 31, 2006.

${ }^{1}$ Corresponding author: benoit.graulet@clermont.inra.fr the amount and AA composition of the RUP in the diet. Individual Met and Lys postruminal infusions have demonstrated that they are the 2 first limiting AA in lactating dairy cows (Schwab et al., 1992; Pisulewski et al., 1996). Methionine has been identified as the first limiting AA when the diet is poor in corn or rich in forage, or also when supplemental RUP is provided by soybean products, animal-derived proteins (except fish), or both (NRC, 2001). An adequate postruminal supply of Met could be achieved using corn gluten meal in the diet, but a Lys limitation would occur concomitantly because of the low content of Lys in this ingredient (only 3.7\% of total essential AA; NRC, 2001). Moreover, feedstuffs with low ruminal degradability and rich in Met, such as fish meal, could be used to increase the postruminal Met and Lys supply (Rulquin and Vérité, 1993), but their use is expensive and is forbidden in Europe because of their animal origin. Finally, the most efficient way to increase the postruminal Met supply is to use "rumen-protected" Met.

Several technologies have been developed to achieve efficient Met protection against ruminal degradation by microorganisms. Determination of the efficacy of these protection technologies has varied according to the mode of protection, but also according to the experimental approach used by the authors. Among physically protected products, the best results have been obtained by coating a core of Met with a matrix of $\mathrm{pH}$-sensitive polymer, such as in Smartamine M (SmM; Adisseo SAS, Antony, France; 78\% Met content). Indeed, the Met bioavailability in SmM was first estimated at $80 \%$ from the determination of its rumen resistance and its intestinal release by nylon bag studies, as reported by Schwab (1995). Methionine bioavailability in SmM was also estimated in lactating dairy cows at 75 to $97 \%$ by digestibility tests (Robert and Williams, 1997) and at approximately $75 \%$ by blood tests (Rulquin and Kowalczyk, 2003). Another proposed strategy for Met protection from rumen degradation was to supply it in the form of chemically modified molecules of Met. Numerous derivatives and analogs of Met (for a detailed list, see Schwab, 1995) have been tested for their resistance to degradation, with the Met hydroxy analog, or D,L-2hydroxy-4-(methylthio)-butanoic acid (HMB), being the 
most studied because it is currently used successfully for Met supply to monogastrics.

As a liquid source, HMB is easy to handle and it can be integrated into pellets. Moreover, HMB is more resistant to rumen degradation than Met, according to in vitro (Vazquez-Añón et al., 2001) and in vivo studies (Langar et al., 1978; Koenig et al., 1999, 2002). However, a controversy exists about the value of the HMB rumen bypass rate. Indeed, relatively low values (9 to $16 \%$ ) were initially observed by Langar et al. (1978) in sheep, and in one study using dairy cows in late lactation, less than $1 \%$ of the dose of HMB supplied reached the small intestine (Jones et al., 1988). By contrast, Koenig et al. (1999, 2002) reported HMB bypass values closer to 40 to $50 \%$ in the rumen of dairy cows in early lactation. This discrepancy could be explained by the difference in the dose level used in the studies, the mode of supplementation, or both by species particularities or by the physiological status of the cows. Moreover, HMB supplementation has a very moderate effect on plasma Met concentrations, which is in contradiction with a rumen bypass value of 50\% (Koenig et al., 1999, 2002). Furthermore, its main effects on milk production and composition were an increase in fat yield, especially when HMB was given repeatedly at doses of 25 to 35 $\mathrm{g} / \mathrm{d}$ to multiparous dairy cows in early lactation receiving an adequate protein supply in the diet, whereas protein yield was not modified and milk production was rarely increased by HMB supplementation (St-Pierre and Sylvester, 2005). Thus, HMB does not seem to be able to effectively meet the Met requirements of lactating cows, at least for milk protein synthesis. Recently, it has been demonstrated that the isopropyl ester of HMB (HMBi) allows a significant Met supply to cows (Graulet et al., 2005) and an increase in their milk protein yield (Noftsger et al., 2005; St-Pierre and Sylvester, 2005).

The objective of this trial was to compare the effects of HMBi, HMB, and SmM on milk production and composition (especially protein content) in conditions in which the 2 Met hydroxyl analogs were integrated into pellets and SmM, used as a positive control, was supplied as a top dressing with the ration.

\section{MATERIALS AND METHODS}

\section{Cows, Diet, and Feeding}

Eight primiparous and 8 multiparous Holstein cows (mean BW: $603 \pm 14 \mathrm{~kg}$ ) were managed in free stalls. Individual feed intake was regulated using troughs with electronically controlled gates (Institut National de la Recherche Agronomique, St-Gilles, France). The trial was initiated immediately after calving, beginning with a conditioning phase ( $8 \mathrm{wk}$ ) and followed by an experimental phase ( $8 \mathrm{wk}$ ). The mean DM composition of the diet was $71.6 \%$ corn silage, $14.6 \%$ energy concentrate, $4.4 \%$ soybean meal ( $48 \% \mathrm{CP}$ ), $7 \%$ formaldehydetreated soybean meal, $1 \%$ urea, and $1.3 \%$ mineral and vitamin supplements (Boviphos; Coopagri, Landernau, France). The compositions of the feeds and diet are presented in Table 1. Diet distribution was limited and amounts were adjusted on the basis of the theoretical requirements of each individual cow in the middle of the experiment (12th week of lactation), as computed by reducing the reference milk yield for multiparous cows by $2 \%$ per week and by reducing the reference milk yield for primiparous cows by $1 \%$. The reference milk yield was the mean of yields recorded during the sixth and seventh weeks of lactation. Depending on the expected yield of each cow, the silage and concentrate supplements were computed to meet energy requirements and $115 \%$ of protein truly digested in the intestine (PDI) requirements (Institut National de la Recherche Agronomique, 1989). Feeds were provided and hand mixed in the troughs at 0900 and $1630 \mathrm{~h}$ in 2 equal parts. Protected AA were deposited on top of the ration in 2 equal amounts each day.

\section{Treatments and Experimental Design}

The 16 cows were divided into 4 homogeneous blocks on the basis of performance data $(4 \% \mathrm{FCM}$, milk protein content, DMI, and BW) recorded during the sixth and the seventh weeks of lactation. One cow per block was assigned to one of the 4 treatments. The experimental design was a $4 \times 4$ Latin square, with 2 -wk periods in which treatments were no supplementation, or rumenprotected Met supplementation with liquid HMBi (MetaSmart; Adisseo SAS, Antony, France; 91.5\% chemical purity), liquid HMB (Alimet; Novus Int. Inc. St. Louis, MO; $88 \%$ chemical purity), or SmM. Both $\mathrm{HMBi}$ and $\mathrm{HMB}$ were incorporated (3\% of the respective products) into soybean meal ( $48 \% \mathrm{CP}$ ) and then pelleted as follows. The soybean meal was first reduced into 3.0-mm particles in a grinder (Sogem Energis, Marzi, France) at 3,000 rpm and then transferred to a blender. The preparation was mixed for $15 \mathrm{~min}$ at $30^{\circ} \mathrm{C}$ and, in the cases of HMB or HMBi treatments, the Met derivatives were sprayed on the soybean meal at the beginning of the mixing. Finally, these feed preparations were pelleted at $4 \mathrm{~mm}$ under industrial conditions. The control treatment was the pelleted soybean meal $(1 \mathrm{~kg} /$ d) alone. When cows were in periods of HMBi and HMB treatments, they received $1 \mathrm{~kg} / \mathrm{d}$ of the respective concentrates. Smartamine M (17 g/d per cow) was added and mixed with the pelleted unsupplemented soybean meal $(1 \mathrm{~kg})$ before feeding. The treatment supplements containing or not containing protected AA were depos- 
Table 1. Chemical composition and nutritive values of feedstuffs and consumed $\operatorname{diet}^{1}$

\begin{tabular}{|c|c|c|c|c|c|}
\hline Item & $\begin{array}{l}\text { Corn } \\
\text { silage }\end{array}$ & $\begin{array}{l}\text { Soybean } \\
\text { meal }\end{array}$ & $\begin{array}{l}\text { Energy } \\
\text { concentrate }\end{array}$ & $\begin{array}{l}\text { Treated } \\
\text { soybean } \\
\text { meal }^{3}\end{array}$ & Diet \\
\hline & & & \multicolumn{3}{|l|}{ (g/kg of DM) } \\
\hline $\mathrm{OM}$ & 960 & 919 & & 925 & 939 \\
\hline $\mathrm{CP}$ & 66 & 515 & 115 & 514 & 153 \\
\hline Crude fiber & 190 & 47 & 114 & 68 & 160 \\
\hline NDF & 412 & 100 & 335 & 218 & 361 \\
\hline $\mathrm{ADF}$ & 210 & 54 & 135 & 78 & 178 \\
\hline Acid detergent lignin & 18 & 6 & 17 & 6 & 16 \\
\hline Ether extract & 30 & 74 & 27 & 31 & 31 \\
\hline $\mathrm{NE}_{\mathrm{L}}, \mathrm{Mcal} / \mathrm{kg}$ of $\mathrm{DM}$ & 1.55 & 2.02 & 1.71 & 2.01 & 1.59 \\
\hline $\mathrm{PDIN},{ }^{4} \mathrm{~g} / \mathrm{kg}$ of DM & 41 & 365 & 81 & 419 & 116 \\
\hline $\mathrm{PDIE}^{4} \mathrm{~g} / \mathrm{kg}$ of $\mathrm{DM}$ & 65 & 248 & 106 & 385 & 100 \\
\hline LysDI, $5 \%$ PDIE & 7.17 & 7.17 & 7.13 & 7.08 & 7.13 \\
\hline MetDI, ${ }^{5} \%$ PDIE & 1.98 & 1.55 & 1.88 & 1.46 & 1.78 \\
\hline
\end{tabular}

\footnotetext{
${ }^{1}$ Diet was supplemented with $215 \mathrm{~g} / \mathrm{d}$ per cow of urea and $270 \mathrm{~g} / \mathrm{d}$ per cow of a trace mineral and vitamin premix (Boviphos; Coopagri, Landernau, France), which contained 5\% P/kg, 25\% Ca/kg, $5 \% \mathrm{Mg} / \mathrm{kg}, 2 \% \mathrm{Na} /$ $\mathrm{kg}, 1,000 \mathrm{mg} / \mathrm{kg}$ of Cu, $1,500 \mathrm{mg} / \mathrm{kg}$ of Fe, $5,000 \mathrm{mg} / \mathrm{kg}$ of Zn, $4,000 \mathrm{mg} / \mathrm{kg}$ of Mn, $20 \mathrm{mg} / \mathrm{kg}$ of Co, $6.7 \mathrm{~g} / \mathrm{kg}$ of Se, $100 \mathrm{mg} / \mathrm{kg}$ of I, 300,000 IU/kg of vitamin A, 80,000 IU/kg of vitamin $\mathrm{D}_{3}$, and $200 \mathrm{mg} / \mathrm{kg}$ of vitamin E.

${ }^{2}$ Dry matter contained $21.8 \%$ ground barley, $21.1 \%$ ground wheat, $15 \%$ fine wheat bran, $37.5 \%$ dehydrated beet pulp, $1.7 \%$ beet molasses, $0.6 \%$ limestone, $1.1 \%$ sodium bicarbonate, and $1.1 \%$ salt.

${ }^{3}$ Spray-treated with $1 \%$ formaldehyde $(30 \%)$ on a raw matter basis.

${ }^{4}$ Proteins truly digested in the small intestine allowed by N (PDIN) or energy (PDIE) and fermented in the rumen. Estimated using equations of the Institut National de la Recherche Agronomique (1989).

${ }^{5}$ Lysine and Met digestible in the intestine estimated using the table of Rulquin et al. (2001).
}

ited each day on top of the ration in 2 equal amounts. The theoretical quantities of Met equivalent supplied were $0,21.3,26.4$, and $13.3 \mathrm{~g} / \mathrm{d}$ for the control, $\mathrm{HMBi}$, HMB, and SmM treatments, respectively. Assuming a Met bioavailability of $50 \%$ for HMBi (Graulet et al., 2005), 40\% for HMB (Koenig et al., 1999), and 80\% for SmM (mean of values previously mentioned), we calculated the quantity of absorbable Met provided by the 3 methionine treatments to be $10.6 \mathrm{~g} / \mathrm{d}$.

\section{Sample Collection and Measurements}

The amount of feed offered and orts were measured daily. Feed samples were collected daily for corn silage and weekly for other feeds. Body weight was measured once a week. Milk yield was measured every day at 0700 and $1630 \mathrm{~h}$ with Metatron 12 automatic samplers (Westfalia Separator, Château Thierry, France). A milk sample was collected mechanically at each milking over $5 \mathrm{~d}$ in each experimental week for analysis of the fat and protein contents of the milk. Milk $(150 \mathrm{~mL})$ was sampled at the morning milking on the fifth day of the last week of each period for analysis of fatty acids (FA) and $\mathrm{CN}$. Blood samples $(10 \mathrm{~mL})$ were drawn at $30 \mathrm{~min}$ before and at 2 and $6 \mathrm{~h}$ after the morning feeding by caudal venipuncture on the fifth day of the last week of each period using heparinized Vacutainers (Beckton Dickison, Meylan, France). After centrifugation for 10 min at $1,450 \times g$, plasma was collected and a mean representative sample for each cow in each period was made by mixing equal amounts of each of the 3 collected samples per cow in the same day. The pooled samples were stored at $-20^{\circ} \mathrm{C}$ until subsequent metabolite analysis.

\section{Chemical Analysis}

Determinations of DM, ash, total N, ADF, NDF, and acid-detergent lignin in feedstuffs as well as the rumen degradability of protein were performed as previously described by Pisulewski et al. (1996). This degradability was used to calculate the PDI values of the feeds (Table 1) according to equations of the Institut National de la Recherche Agronomique (1989). The HMBi content in the soybean meal concentrate was assayed from a 5.0$\mathrm{g}$ sample of the feed ground to $0.5 \mathrm{~mm}$. The HMBi was extracted from the meal by a 30 -min incubation at room temperature under agitation in $250 \mathrm{~mL}$ of a solution of methyl alcohol:water:phosphoric acid (500:500:1). The preparation was filtered on a $0.45-\mu \mathrm{m}$ filter (Millipore, Molsheim, France), and HMBi was quantified in the samples by UV detection at $210 \mathrm{~nm}$ after separation by HPLC on a Hypersil Elite HyPURITY C18 column (150 $\times 4.6 \mathrm{~mm}, 5 \mu \mathrm{m}$; Thermo Electron Corp., Madison, WI) under isocratic conditions. The mobile phase was a mix $(80: 20)$ of acetonitrile and water acidified to $\mathrm{pH} 2.0$ with 
phosphoric acid distributed at a flow rate of $0.9 \mathrm{~mL} /$ min. The injection volume of the samples was $10 \mu \mathrm{L}$. The quantification limits were 0.5 and $60 \mathrm{~g} / \mathrm{kg}$, with a mean recovery yield of $96 \%$. Intra- and interassay variations were lower than $0.4 \%$ and $7 \%$, respectively. The HMB content in the soybean meal concentrate was assayed from a 5.0-g sample of the feed ground to 0.5 $\mathrm{mm}$. The HMB was extracted from the resulting flour by incubation for $60 \mathrm{~min}$ at $45^{\circ} \mathrm{C}$ in a shaking water bath with $50 \mathrm{~mL}$ of a solution of acetonitrile:water (100:900). The preparation was cooled by incubation in cold water for several min and then centrifuged at 3,000 $\times g$. The supernatant was collected and the pellet was treated one more time with an additional $50 \mathrm{~mL}$ of solution (incubation and centrifugation). The supernatants were pooled and then treated with $1 \mathrm{~mL}$ of $50 \%$ potassium hydroxide, with shaking for $1 \mathrm{~min}$. The solution was mixed for $30 \mathrm{~s}$ with $1 \mathrm{~mL}$ of $85 \%$ orthophosphoric acid and centrifugated for $10 \mathrm{~min}$ at $8,100 \times \mathrm{g}$. Finally, the supernatant was collected and filtered on a $0.22-\mu \mathrm{m}$ filter (Millipore). The HMB was quantified in the samples by UV detection at $214 \mathrm{~nm}$ after separation on a Hibar prepacked RT-250-4 LichroSorb RP-18 column (5 $\mu \mathrm{m}$; Merck KgA, Darmstadt, Germany) under isocratic conditions with an HP 1100 HPLC apparatus (Agilent Technologies, Palo Alto, CA). The mobile phase was a solution of acetonitrile:water acidified to $\mathrm{pH} 2.0$ with $85 \%$ orthophosphoric acid (8:92) distributed at a flow rate of $0.8 \mathrm{~mL} / \mathrm{min}$. The injection volume of the samples was $20 \mu \mathrm{L}$. The linearity of HMB quantification was demonstrated between 0.2 and $5.1 \mathrm{~g} / \mathrm{kg}$. The intraand interassay variations were less than $5 \%$ and less than $7 \%$, respectively.

Plasma concentrations of glucose, NEFA, BHBA, and urea were determined as described by Pisulewski et al. (1996). The total glycerol (assimilated to triacylglycerols) was assayed with an enzymatic kit (Biotrol Diagnostic, Chennevières-lès-Louvres, France). The Met assay was performed as previously reported (Südekum et al., 2004; Graulet et al., 2005). Briefly, the macromolecular nitrogen in $1,000 \pm 0.1 \mathrm{mg}$ of plasma sample was precipitated by treatment with $10 \%$ (vol/wt) of 3.15 $M$ 5-sulfosalicylic acid. After centrifugation for $10 \mathrm{~min}$ at room temperature and $11,670 \times g$, the supernatant was collected. The pellet was washed several times with a lithium salt buffer, $\mathrm{pH} 2.2$, containing $33.3 \mathrm{mM}$ trilithium citrate (Merck KGaA), $35.2 \mathrm{mM}$ citric acid, 0.5\% thiodiethylene glycol (Sigma Chemical Co., St. Louis, MO), $0.28 \%$ hydrochloric acid, and finally octanoic acid ( 2 drops for $2 \mathrm{~L}$ of buffer), and the supernatants were pooled. The final volume was adjusted to $5.0 \mathrm{~mL}$ with the lithium salt buffer and the preparation was filtered on a $0.22-\mu \mathrm{m}$ filter before storage at $4^{\circ} \mathrm{C}$ until assay. The Met concentration was determined in $50 \mu \mathrm{L}$ of sample by ion-exchange chromatography using a Beckman 6300 AA analyzer (Beckman Instruments, Palo Alto, CA) at $570 \mathrm{~nm}$ after postcolumn ninhydrin derivatization at $125^{\circ} \mathrm{C}$. Methionine concentrations in the plasma samples were expressed as $\mu M$ after correction for calibration adjustment, internal standard variations, and dilution values.

Fat and protein contents of milk were determined by infrared analysis (MilkoScan; Foss Electric, Hillerød, Denmark). Milk CN content and FA composition were analyzed as described by Pisulewski et al. (1996).

\section{Statistical Analysis}

Statistical analysis of data was performed according to ANOVA using the GLM procedure of SAS (SAS Institute, 1987) and the following model $\mathrm{Y}_{\mathrm{ijk}}=\alpha_{\mathrm{i}}+\beta_{\mathrm{j}}+\gamma_{\mathrm{k}}$ $+\varepsilon_{\mathrm{ijk}}$, where the main sources of variation were $\alpha_{\mathrm{i}}$, the cow effect; $\beta_{\mathrm{j}}$, the period effect; $\gamma_{\mathrm{k}}$, the treatment effect; and $\varepsilon_{\mathrm{ijk}}$, the residual effects. When the treatment effect was significant, differences were assessed by use of Fisher's protected least significant differences test.

\section{RESULTS}

\section{Feed Intake}

Methionine supplements were provided in pellets that were mainly composed of soybean meal. No orts were noticed for the total ration or the pelleted treatments. Analytical determination of HMBi and HMB content in the soybean meal pellets gave some differences from the expected values. Indeed, data on HMBi incorporation into soybean meal gave $16.9 \mathrm{~g}$ of Met equivalent $/ \mathrm{kg}$, whereas 21.3 was the expected value. Considering a 50\% Met bioavailability in $\mathrm{HMBi}$ (Graulet et al., 2005), the estimated intestinal digestible Met (MetDI) supply would be $8.5 \mathrm{~g} / \mathrm{cow}$ per day instead of $10.6 \mathrm{~g}$. Data on HMB incorporation into soybean meal indicated $29.6 \mathrm{~g}$ of Met equivalent $/ \mathrm{kg}$ instead of the expected value of 26.4. Consequently, we assumed the Met equivalent intake to be $29.6 \mathrm{~g} / \mathrm{cow}$ per day. Considering a $40 \%$ Met bioavailability in HMB (Koenig et al., 1999, 2002), the estimated MetDI supply would be $11.8 \mathrm{~g} / \mathrm{cow}$ per day instead of $10.6 \mathrm{~g}$, the expected absorbable Met provided by SmM supplementation.

The nature of rumen-protected Met supplementation did not affect total DM or nutrient intake (Table 2). The cows were not fed 100 and $115 \%$ of their energy and protein requirements as expected, but 95 and $106 \%$, respectively. However, the $\mathrm{NE}_{\mathrm{L}}$ balance remained similar between treatments and was not significantly different from zero (Table 3). 
Table 2 Effects of Met supplements on feed and nutrient intakes ${ }^{1}$

\begin{tabular}{|c|c|c|c|c|c|}
\hline Item & Control & $\mathrm{HMBi}$ & HMB & $\mathrm{SmM}$ & $\mathrm{SE}$ \\
\hline \multicolumn{6}{|l|}{ DMI, kg/d } \\
\hline Corn silage & 14.7 & 14.9 & 14.5 & 15.0 & 1.65 \\
\hline Energy concentrate & 2.97 & 2.96 & 3.00 & 3.09 & 1.51 \\
\hline Treated soybean meal & 1.43 & 1.44 & 1.45 & 1.46 & 0.31 \\
\hline Soybean meal & 0.88 & & & 0.88 & 0 \\
\hline Concentrate $\mathrm{HMB}^{2}$ & & & 0.88 & & 0 \\
\hline Concentrate $\mathrm{HMBi}^{3}$ & & 0.88 & & & 0 \\
\hline Smartamine M & & & & 0.017 & 0 \\
\hline Urea & 0.21 & 0.21 & 0.22 & 0.21 & 0.08 \\
\hline Minerals & 0.27 & 0.27 & 0.27 & 0.27 & 0.10 \\
\hline Total intake & 20.5 & 20.7 & 20.3 & 20.9 & 2.32 \\
\hline \multicolumn{6}{|l|}{ Nutrient intake } \\
\hline Energy, Mcal of $\mathrm{NE}_{\mathrm{L}} / \mathrm{d}$ & 32.6 & 33.0 & 32.5 & 33.2 & 3.88 \\
\hline $\mathrm{CP}, \mathrm{g} / \mathrm{d}$ & 3,118 & 3,127 & 3,111 & 3,156 & 343 \\
\hline $\mathrm{PDIE}^{4}, \mathrm{~g} / \mathrm{d}$ & 2,047 & 2,065 & 2,045 & 2,096 & 288 \\
\hline $\mathrm{PDIN},{ }^{4} \mathrm{~g} / \mathrm{d}$ & 2,378 & 2,384 & 2,378 & 2,415 & 257 \\
\hline
\end{tabular}

${ }^{1} \mathrm{HMBi}=$ hydroxy-methylthio-butanoic isopropyl ester; $\mathrm{HMB}$ = hydroxy-methylthio-butanoic acid; $\mathrm{SmM}=$ Smartamine M (Adisseo SAS, Antony, France).

${ }^{2} \mathrm{DM}$ composition: $3 \%$ Alimet (HMB; Novus Int. Inc., St. Louis, MO; 88\% chemical purity), 97\% soybean meal.

${ }^{3} \mathrm{DM}$ composition: 3\% MetaSmart (HMBi; Adisseo SAS, Antony, France; 91.5\% chemical purity), 97\% soybean meal.

${ }^{4}$ Proteins truly digested in the small intestine allowed by $\mathrm{N}$ (PDIN) or energy (PDIE) and fermented in the rumen. Estimated using equations of the Institut National de la Recherche Agronomique (1989).

\section{Plasma Metabolites}

Plasma glucose, NEFA, triacylglycerols, BHBA, and urea concentrations were not affected by the source of Met supply (Table 4). The plasma Met concentration was increased by the $\mathrm{HMBi}(+110 \%, P<0.05)$ and $\mathrm{SmM}$ treatments $(+65 \%, P<0.05)$ but was not affected by the HMB treatment compared with the control.

\section{Milk Production and Composition}

There were no effects of Met source on BW, milk yield, $4 \% \mathrm{FCM}$, milk fat yield, and milk fat percentage
(Table 3). However, milk true protein yield, true protein content, and true $\mathrm{CN}$ content were significantly affected by the Met source. Compared with the control, milk protein yield increased by $32 \mathrm{~g} / \mathrm{d}(P<0.05)$ with $\mathrm{HMBi}$ and by $41 \mathrm{~g} / \mathrm{d}(P<0.05)$ with SmM (Table 3$)$. In the same way, true protein content was increased by $\mathrm{HMBi}$ $(+0.10 \%, P<0.05)$ and $\mathrm{SmM}(+0.07 \%, P<0.05)$. Casein content was increased by HMBi treatment $(+0.08 \%, P$ $<0.05$; Table 3) but not by SmM. The ratio of $\mathrm{CN}$ to protein was not affected by the Met supplement.

Milk FA composition was affected by the Met source (Table 5). Compared with the control, HMB increased

Table 3. Effects of Met supplements on BW, lactational performance, and nutrient balances ${ }^{1}$

\begin{tabular}{|c|c|c|c|c|c|}
\hline Item & Control & $\mathrm{HMBi}$ & HMB & $\mathrm{SmM}$ & $\mathrm{SE}$ \\
\hline $\mathrm{BW}, \mathrm{kg}$ & 614 & 614 & 613 & 615 & 8 \\
\hline \multicolumn{6}{|l|}{ Milk production } \\
\hline Milk yield, kg/d & 31.4 & 31.5 & 31.8 & 32.0 & 1.4 \\
\hline 4\% FCM yield, $\mathrm{kg} / \mathrm{d}$ & 31.9 & 32.1 & 32.8 & 32.5 & 1.5 \\
\hline Fat yield, $g / d$ & 1,291 & 1,300 & 1,337 & 1,312 & 66 \\
\hline True protein yield, g/d & $962^{\mathrm{b}}$ & $994^{\mathrm{a}}$ & $980^{\mathrm{ab}}$ & $1,003^{\mathrm{a}}$ & 38 \\
\hline \multicolumn{6}{|l|}{ Milk composition } \\
\hline Fat, \% & 4.16 & 4.20 & 4.26 & 4.16 & 0.15 \\
\hline True protein, \% & $3.09^{\mathrm{b}}$ & $3.19^{\mathrm{a}}$ & $3.10^{\mathrm{b}}$ & $3.16^{\mathrm{a}}$ & 0.07 \\
\hline $\mathrm{CN}, \%$ & $2.60^{\mathrm{b}}$ & $2.68^{\mathrm{a}}$ & $2.57^{\mathrm{b}}$ & $2.62^{\mathrm{b}}$ & 0.07 \\
\hline CN:protein, \% & 83.9 & 84.0 & 83.1 & 82.9 & 1.7 \\
\hline \multicolumn{6}{|l|}{ Nutrient balances } \\
\hline $\mathrm{NE}_{\mathrm{L}}, \mathrm{Mcal} / \mathrm{d}$ & -1.36 & -1.19 & -2.38 & -1.53 & 1.48 \\
\hline PDI, g/d & 151 & 121 & 124 & 109 & 74 \\
\hline
\end{tabular}

${ }^{\mathrm{a}, \mathrm{b}}$ Means within a row with different superscripts differ $(P<0.05)$.

${ }^{1} \mathrm{HMBi}=$ hydroxy-methylthio-butanoic isopropyl ester; HMB = hydroxy-methylthio-butanoic acid; PDI = protein truly digested in the small intestine; SmM = Smartamine M (Adisseo SAS, Antony, France). 
Table 4. Effects of Met supplementation on some plasma metabolites ${ }^{1}$

\begin{tabular}{lccccc}
\hline Item & Control & HMBi & HMB & SmM & SE \\
\hline Glucose, $\mathrm{m} M$ & 3.56 & 3.59 & 3.52 & 3.56 & 0.14 \\
NEFA, $\mu M$ & 124 & 108 & 128 & 128 & 42 \\
Triacylglycerols, mg/L & 54.7 & 54.3 & 55.8 & 56.9 & 6.2 \\
BHBA, mM & 0.81 & 0.75 & 0.85 & 0.80 & 0.18 \\
Urea, $\mathrm{m} M$ & 5.29 & 5.09 & 5.04 & 5.22 & 0.44 \\
Met, $\mu M$ & $16.49^{\mathrm{c}}$ & $34.65^{\mathrm{a}}$ & $14.81^{\mathrm{c}}$ & $27.18^{\mathrm{b}}$ & 6.04 \\
\hline
\end{tabular}

${ }^{\mathrm{a}-\mathrm{c}}$ Means within a row with different superscripts differ $(P<0.05)$.

${ }^{1} \mathrm{HMBi}=$ hydroxy-methylthio-butanoic isopropyl ester; $\mathrm{HMB}=$ hydroxy-methylthio-butanoic acid; $\mathrm{SmM}=$ Smartamine M (Adisseo SAS, Antony, France).

the proportion in $15: 0$ by 0.23 percentage units $(P<$ 0.05 ), and $\mathrm{SmM}$ increased the level of saturation of total $\mathrm{C}_{18} \mathrm{FA}$, because the 18:0 content increased by 0.40 percentage units and 18:2 decreased by 0.08 percentage units $(P<0.05)$, whereas 18:1 was not affected. The HMBi treatment induced several modifications in the milk FA composition. Like SmM, HMBi induced an increase in the level of saturation of $\mathrm{C}_{18} \mathrm{FA}$ : The 18:0 content increased by 0.66 percentage units and 18:2 decreased by 0.12 percentage units $(P<0.05)$ without affecting the 18:1 content. Moreover, like HMB, HMBi increased the proportion in 15:0 (+0.32 percentage units, $P<0.05)$. Furthermore, it increased the 17:0 content $(+0.11 \%)$, although not significantly. Finally, $\mathrm{HMBi}$ treatment also induced a general reduction $(-1.51 \%)$ in short- and medium-chain FA in the milk $\left(\mathrm{C}_{6}\right.$ to $\left.\mathrm{C}_{14}\right)$.

Table 5. Effects of Met supplementations on the milk fatty acid composition $^{1}$

\begin{tabular}{|c|c|c|c|c|c|}
\hline $\begin{array}{l}\text { Fatty } \\
\text { acid }\end{array}$ & Control & HMBi & HMB & $\mathrm{SmM}$ & $\mathrm{SE}$ \\
\hline & \multicolumn{4}{|c|}{ (g/100 g of fatty acids) } & \\
\hline $4: 0$ & 2.64 & 2.64 & 2.57 & 2.62 & 0.06 \\
\hline $6: 0$ & $2.19^{\mathrm{ab}}$ & $2.12^{\mathrm{c}}$ & $2.16^{\mathrm{b}}$ & $2.20^{\mathrm{a}}$ & 0.02 \\
\hline $8: 0$ & $1.47^{\mathrm{a}}$ & $1.37^{\mathrm{b}}$ & $1.43^{\mathrm{a}}$ & $1.46^{\mathrm{a}}$ & 0.02 \\
\hline $10: 0$ & $3.44^{\mathrm{a}}$ & $3.13^{\mathrm{b}}$ & $3.40^{\mathrm{a}}$ & $3.48^{\mathrm{a}}$ & 0.10 \\
\hline $12: 0$ & $4.28^{\mathrm{a}}$ & $3.82^{\mathrm{b}}$ & $4.27^{\mathrm{a}}$ & $4.29^{\mathrm{a}}$ & 0.15 \\
\hline $14: 1$ & $1.17^{\mathrm{ab}}$ & $1.09^{c}$ & $1.21^{\mathrm{a}}$ & $1.14^{\mathrm{bc}}$ & 0.04 \\
\hline 14:0 & 12.87 & 12.38 & 12.90 & 12.86 & 0.24 \\
\hline iso-15:1 & 0.22 & 0.21 & 0.23 & 0.22 & 0.01 \\
\hline $15: 1$ & 0.52 & 0.51 & 0.53 & 0.51 & 0.01 \\
\hline $15: 0$ & $1.27^{\mathrm{b}}$ & $1.59^{\mathrm{a}}$ & $1.50^{\mathrm{a}}$ & $1.25^{\mathrm{b}}$ & 0.08 \\
\hline $16: 1$ & 1.84 & 1.83 & 1.84 & 1.81 & 0.04 \\
\hline $16: 0$ & 41.23 & 41.34 & 40.73 & 40.97 & 0.41 \\
\hline iso-17:1 & 0.32 & 0.30 & 0.33 & 0.32 & 0.03 \\
\hline $17: 1$ & 0.77 & 0.79 & 0.76 & 0.75 & 0.03 \\
\hline $17: 0$ & 0.56 & 0.67 & 0.60 & 0.56 & 0.03 \\
\hline $18: 2$ & $2.05^{\mathrm{a}}$ & $1.93^{\mathrm{b}}$ & $1.98^{\mathrm{ab}}$ & $1.97^{\mathrm{b}}$ & 0.05 \\
\hline 18:1 & 15.06 & 15.57 & 15.26 & 15.09 & 0.39 \\
\hline 18:0 & $8.10^{c}$ & $8.76^{\mathrm{a}}$ & $8.32^{\mathrm{bc}}$ & $8.50^{\mathrm{ab}}$ & 0.20 \\
\hline
\end{tabular}

${ }^{\mathrm{a}-\mathrm{c}}$ Means within a row with different superscripts differ $(P<0.05)$.

${ }^{1} \mathrm{HMBi}=$ hydroxy-methylthio-butanoic-isopropyl ester; $\mathrm{HMB}=$ hydroxy-methylthio-butanoic acid; SmM = Smartamine M (Adisseo SAS, Antony, France).

\section{DISCUSSION}

\section{Feed and Met Intake}

The energy balance of cows was slightly negative, although not significantly different from zero with the current experiment. In a previous experiment, we demonstrated that the response to rumen-protected Met supplementation was similar between lactating cows in negative or positive energy balance (Rulquin and Delaby, 1997). Moreover, in the same experiment, the lack of interaction between the energy balance and Met supplementation was also shown.

In the current study, MetDI and Lys contents in the basal ration where 1.78 and $7.13 \%$ of the PDI (Table 1 ), whereas the requirements proposed for lactating cows are 2.5 and $7.3 \%$ (Rulquin et al., 1993), indicating that the diet was deficient in Met and not in Lys.

\section{Lactation Performance}

In the present work, supplementation of the Metdeficient diet with SmM or HMBi improved milk protein yield and true protein content. The beneficial effect of SmM on milk protein synthesis has been reported previously, both in energy-deficient and in energy-sufficient diets (Schwab, 1995; Rulquin and Delaby, 1997). The increase in milk protein yield $(+41 \mathrm{~g} / \mathrm{d})$ obtained with the SmM treatment (13.3 $\mathrm{g}$ of Met equivalent/d) was similar to the response $(+43 \mathrm{~g} / \mathrm{d})$ when $12 \mathrm{~g} / \mathrm{d}$ of Met was infused into the duodenum (Pisulewski et al., 1996) and was higher than responses (average of $20 \mathrm{~g} /$ d) obtained by Rulquin and Delaby (1994) with $24 \mathrm{~g} / \mathrm{d}$ of SmM. Moreover, SmM supplementation induced an increase in plasma Met concentrations, as previously observed by several authors (Rulquin and Delaby, 1997; Südekum et al., 2004). These observations confirm the efficiency of SmM in providing Met to the dairy cow, especially for milk protein synthesis by the mammary gland (Schwab, 1995; Armentano et al., 1997). Supplementation with HMBi (16.9 g Met equivalent/d) also increased plasma Met concentrations $(\times 2)$ and milk protein yield $(+32 \mathrm{~g} / \mathrm{d})$ and content $(+0.10 \%)$, indicating 
that HMBi also provided significant amounts of Met to the cow. In 2 recent studies, it was demonstrated that supplementing the diets of lactating dairy cows with liquid HMBi mixed with a clay (powder presentation) improved the milk protein performance (Noftsger et al., 2005; St-Pierre and Sylvester, 2005). Moreover, in the present paper, HMBi supplementation supplied Met available for milk protein synthesis by lactating dairy cows when it was provided in a liquid form integrated into the diet in pelleted soybean meal. From the Met equivalent supplied and respective responses in milk protein yield obtained with SmM and HMBi in this trial, the Met bioavailability in HMBi was calculated to be $61 \%$ that of SmM. Moreover, by assuming a mean Met bioavailability of SmM of $80 \%$, the Met bioavailability in HMBi could be estimated at $49 \%$. This estimation is in agreement with the Met bioavailablity value recently determined by a blood test approach (Graulet et al., 2005). In the present study, the dietary supplementation with HMBi induced an increase in the plasma Met concentration that confirmed its efficiency in supplying Met to the lactating cow. Surprisingly, this increase was largely higher than the one observed after SmM supplementation. However, the present experiment was not designed to quantify the rumen-protected Met supply through the plasma Met concentration. Thus, this unexpected result could be explained by the schedule of blood sampling, because plasma Met concentrations after HMBi or SmM supplementation followed distinct evolutions, as previously reported (Graulet et al., 2005).

The HMBi significantly increased the CN percentage in milk protein. This latter result was in agreement with previous observations realized in our laboratory demonstrating that the increase in protein content after Met postruminal infusions resulted from an increase in the $\mathrm{CN}$ (essentially the $\beta$-CN) but not the whey protein content (Pisulewski et al., 1996). In the present paper, SmM supplementation did not increase the CN content in milk or the ratio of $\mathrm{CN}$ to milk protein, whereas the opposite results have previously been observed (Rulquin and Delaby, 1994, 1997). This discrepancy is not fully understood because experimental conditions (lactation stage, energy and protein balance, supplement doses) were very similar to those of Rulquin and Delaby (1994, 1997).

In our experiment, HMB supplementation did not increase the milk yield or affect the milk composition, including the percentage of fat. The most consistent response to HMB supplementation of lactating dairy cow rations, based in the literature, is an increase in milk fat percentage (Hansen et al., 1991) and sometimes milk yield (Piepenbrink et al., 2004). We could suppose that the Latin square design (short-term pe- riod) of our study did not allow HMB to produce significant effects on fat metabolism because these latter ones would be mediated by long-term modifications of the rumen fermentation (Schwab, 1995). By contrast, the ineffectiveness of HMB in increasing the milk protein content was similar to previous findings (Piepenbrink et al., 2004) and consistent with the absence of an effect of HMB on the plasma Met concentration. Indeed, effects of HMB on milk protein and plasma Met concentrations have been rare and minimal (NRC, 2001), indicating that HMB is not a good substitute for Met in ruminants.

\section{Milk FA}

Supplementation of the dairy cow ration with $\mathrm{SmM}$ or HMBi increased the 18:0 content and reduced the 18:2 content in milk lipids. Rulquin and Delaby (1997) also reported a reduction in 18:2 in milk with SmM supplementation, whereas Pisulewski et al. (1996) demonstrated a quadratic effect of the dose of Met supplementation (with the optimal value at $12 \mathrm{~g} / \mathrm{d}$ ) on the 18:0 content in milk. Milk FA with carbon numbers greater than 16 are not produced in the mammary gland but originate from the plasma lipids as NEFA because of mobilization of the body fat stores (adipose tissues) or as part of triacylglycerols circulating in lipoproteins (chylomicrons from the digestive tract of very low density lipoproteins from the liver). It is unlikely that the biohydrogenation of FA by the ruminal microorganisms would be affected by Met postruminal infusions (Pisulewski et al., 1996) or SmM supplementation (Rulquin and Delaby, 1997). The stearoyl-coenzyme A desaturase activity is not very efficient in the bovine liver (St-John et al., 1991); consequently, it is the most probable that Met supplementation by SmM or HMBi would decrease its activity in the mammary gland or in the adipose tissues.

Supplementation of the ration by pellets containing Met derivatives (HMB or HMBi) induced an increase in saturated odd-numbered FA (mainly 15:0 but also 17:0 for HMBi, although not significantly). These FA are considered as markers of rumen microbial activity (Vlaeminck et al., 2005). Consequently, the increase in these FA in milk would indicate a stimulation of rumen microbial growth in cows supplemented with HMBi and HMB. This conclusion is supported by the increases in digestibility of NDF and OM substrates previously observed in vitro with HMBi or HMB (Noftsger et al., 2005).

Finally, a decrease in the percentage of even-numbered short- and medium-chain FA $\left(\mathrm{C}_{6}\right.$ to $\left.\mathrm{C}_{14}\right)$ in milk fat was also observed after HMBi supplementation. Taken together, these results suggest that the mam- 
mary gland of lactating dairy cows supplemented with HMBi would reduce de novo FA synthesis inversely proportional to the increase in the uptake of plasma NEFA, including odd-chain FA of rumen microbial origin.

\section{CONCLUSIONS}

Methionine supplementation of a ration specifically deficient in this AA with a product protected from rumen degradation by a $\mathrm{pH}$-sensitive coating, such as $\mathrm{SmM}$, improves milk protein yield and content, but this kind of product cannot be incorporated into the concentrate. The present paper demonstrates that the isopropyl ester of HMB (HMBi) is a new form of rumen-protected Met that can be incorporated into pelleted concentrates that allows for increased milk protein synthesis, which is not the case with the original HMB. The use of HMBi will thus favor the generalization of Met supplementation in the formulation of dairy cow diets.

\section{REFERENCES}

Armentano, L. E., S. J. Bertics, and G. A. Ducharme. 1997. Response of lactating cows to methionine or methionine plus lysine added to high protein diets based on alfalfa and heated soybeans. J. Dairy Sci. 80:1194-1199.

Graulet, B., C. Richard, and J. C. Robert. 2005. Methionine availability in plasma of dairy cows supplemented with methionine hydroxy analog isopropyl ester. J. Dairy Sci. 88:3640-3649.

Hansen, W. P., D. E. Otterby, J. G. Linn, and J. D. Donker. 1991. Influence of forage type, ratio of forage to concentrate, and methionine hydroxy analog on performance of dairy cows. J. Dairy Sci. 74:1361-1369.

Institut National de la Recherche Agronomique. 1989. Ruminant Nutrition: Recommended Allowances and Feed Tables. R. Jarrige, ed. J. Libbey Eurotext, Paris, France.

Jones, B. A., O. E. Mohamed, R. W. Prange, and L. D. Satter. 1988. Degradation of methionine hydroxy analog in the rumen of lactating cows. J. Dairy Sci. 71:525-529.

Koenig, K. M., L. M. Rode, C. D. Knight, and P. R. McCullough. 1999. Ruminal escape, gastrointestinal absorption, and response of serum methionine to supplementation of liquid methionine hydroxy analog in dairy cows. J. Dairy Sci. 82:355-361.

Koenig, K. M., L. M. Rode, C. D. Knight, and M. Vázquez-Añón. 2002. Rumen degradation and availability of various amounts of liquid methionine hydroxy analog in lactating dairy cows. J. Dairy Sci. 85:930-938.

Langar, P. N., P. J. Buttery, and D. Lewis. 1978. N-stearoyl-DLmethionine, a protected methionine source for ruminants. J. Sci. Feed Agric. 29:808-814.

National Research Council. 2001. Protein and amino acids. Pages 43-104 in Nutrient Requirements of Dairy Cattle. 7th rev. ed. Natl. Acad. Sci., Washington, DC.
Noftsger, S., N. R. St-Pierre, and J. T. Sylvester. 2005. Determination of rumen degradability and ruminal effects of three sources of methionine in lactating cows. J. Dairy Sci. 88:223-237.

Piepenbrink, M. S., A. L. Marr, M. R. Waldron, W. R. Butler, T. R. Overton, M. Vazquez-Añón, and M. D. Holt. 2004. Feeding 2hydroxy-4-(methylthio)-butanoic to periparturient dairy cows improves milk production but not hepatic metabolism. J. Dairy Sci. 87:1071-1084.

Pisulewski, P. M., H. Rulquin, J. L. Peyraud, and R. Vérité. 1996. Lactational and systemic responses of dairy cows to postruminal infusions of increasing amounts of methionine. J. Dairy Sci. 79:1781-1791.

Robert, J. C., and P. Williams. 1997. Influence of forage type on the intestinal availability of methionine from a rumen protected form. J. Dairy Sci. 80(Suppl. 1):248. (Abstr.)

Rulquin, H., and L. Delaby. 1997. Effects of the energy balance of dairy cows on lactational responses to rumen-protected methionine. J. Dairy Sci. 80:2513-2522.

Rulquin, H., and L. Delaby. 1994. Lactational responses of dairy cows to graded amounts of rumen-protected methionine. J. Dairy Sci. 72(Suppl. 1):91. (Abstr.)

Rulquin, H., P. M. Pisulewski, R. Vérité, and J. Guinard. 1993. Milk production and composition as a function of postruminal lysine and methionine supply: A nutrient-response approach. Livest. Prod. Sci. 37:69-90.

Rulquin, H., and R. Vérité. 1993. Amino acid nutrition of dairy cows: Productive effects and animal requirements. Pages 55-77 in Recent Advances in Animal Nutrition. P. C. Garnsworthy and D. J. A. Cole, ed. Nottingham Univ. Press, Nottingham, UK.

Rulquin, H., R. Vérité, and J. Guinard-Flament. 2001. Tables des valeurs AADI des aliments des ruminants. INRA Prod. Anim. 14(Suppl.):1-16.

Rulquin, H., and J. Kowalczyk. 2003. Development of a method for measuring lysine and methionine bioavailability in rumen-protected products for cattle. J. Anim. Feed Sci. 12:465-474.

SAS Institute. 1987. SAS User's Guide: Statistics. 6th ed. SAS Institute, Inc., Cary, NC.

Schwab, C. G., C. K. Bozak, N. L. Whitehouse, and M. M. A. Mesbah. 1992. Amino acid limitation and flow at duodenum at four stages of lactation. 1. Sequence of lysine and methionine limitation. J. Dairy Sci. 75:3486-3502.

Schwab, C. G. 1995. Protected proteins and amino acids for ruminants. Pages 115-141 in Biotechnology in Animal Feeds and Animal Feeding. R. J. Wallace and A. Chesson, ed. VCH Publishers, New York, NY.

St-John, L. C., D. K. Lunt, and S. B. Smith. 1991. Fatty acid elongation and desaturation enzyme activities of bovine liver and subcutaneous adipose tissue microsomes. J. Anim. Sci. 69:1064-1073.

St-Pierre, N. R., and J. T. Sylvester. 2005. Effects of 2-hydroxy-4(methylthio) butanoic acid (HMB) and its isopropyl ester on milk production and composition by Holstein cows. J. Dairy Sci. 88:2487-2497.

Südekum, K. H., S. Wolffram, P. Ader, and J. C. Robert. 2004. Bioavailability of three ruminally protected methionine sources in cattle. Anim. Feed Sci. Technol. 113:17-25.

Vazquez-Añón, M., T. Cassidy, P. McCullough, and G. A. Varga. 2001. Effects of Alimet on nutrient digestibility, bacterial protein synthesis, and ruminal disappearance during continuous culture. J. Dairy Sci. 84:159-166.

Vlaeminck, B., C. Dufour, A. M. van Vuuren, A. R. Cabrita, R. J. Dewhurst, D. Demeyer, and V. Fievez. 2005. Use of odd and branched-chain fatty acids in rumen contents and milk as a potential microbial marker. J. Dairy Sci. 88:1031-1042. 